\title{
Distal versus proximal intestinal short-chain fatty acid release in man
}

Citation for published version (APA):

Neis, E. P. J. G., van Eijk, H. M. H., Lenaerts, K., Damink, S. W. M. O., Blaak, E. E., Dejong, C. H. C., \& Rensen, S. S. (2019). Distal versus proximal intestinal short-chain fatty acid release in man. Gut, 68(4), 764-765. https://doi.org/10.1136/gutjnl-2018-316161

Document status and date:

Published: 01/04/2019

DOI:

10.1136/gutjnl-2018-316161

Document Version:

Publisher's PDF, also known as Version of record

Document license:

Taverne

Please check the document version of this publication:

- A submitted manuscript is the version of the article upon submission and before peer-review. There can be important differences between the submitted version and the official published version of record.

People interested in the research are advised to contact the author for the final version of the publication, or visit the DOI to the publisher's website.

- The final author version and the galley proof are versions of the publication after peer review.

- The final published version features the final layout of the paper including the volume, issue and page numbers.

Link to publication

\footnotetext{
General rights rights.

- You may freely distribute the URL identifying the publication in the public portal. please follow below link for the End User Agreement:

www.umlib.nl/taverne-license

Take down policy

If you believe that this document breaches copyright please contact us at:

repository@maastrichtuniversity.nl

providing details and we will investigate your claim.
}

Copyright and moral rights for the publications made accessible in the public portal are retained by the authors and/or other copyright owners and it is a condition of accessing publications that users recognise and abide by the legal requirements associated with these

- Users may download and print one copy of any publication from the public portal for the purpose of private study or research.

- You may not further distribute the material or use it for any profit-making activity or commercial gain

If the publication is distributed under the terms of Article $25 \mathrm{fa}$ of the Dutch Copyright Act, indicated by the "Taverne" license above, 


\section{Distal versus proximal intestinal short-chain fatty acid release in man}

Several recent studies published in Gut highlight the potential of prebiotics and short-chain fatty acids (SCFAs) to improve obesity and its associated metabolic disorders. Catry and colleagues ${ }^{1}$ demonstrated that inulin-type fructans improve endothelial dysfunction, and Roager et $a l^{2}$ showed that a whole grain-rich diet reduced body weight and inflammation. Li et $a l^{3}$ reported that butyrate administration reduced appetite and activated brown adipose tissue in mice, and Chambers and colleagues ${ }^{4}$ showed that targeted propionate delivery to the human colon reduced energy intake and body weight gain.

In light of these important effects of SCFA, insight into their fate after bacterial production and/or intestinal absorption will help to improve the development of nutritional strategies aiming at modulation of intestinal SCFA. We addressed this issue by assessing SCFA release in the proximal intestines (jejunum, ileum and proximal colon) versus the distal intestines (descending colon, sigmoid and rectum) in man. Blood was simultaneously sampled from the portal vein, hepatic vein, superior mesenteric vein (SMV; draining the proximal intestines), inferior mesenteric vein (IMV; draining the distal intestines) and the radial artery in 20 patients undergoing upper abdominal surgery (see online supplementary table for patient characteristics).

SCFA concentrations were highest in the IMV and lowest in the radial artery (table 1). Acetate concentrations in the IMV and SMV were strongly correlated $\left(\mathrm{r}_{\mathrm{s}}=0.57, \mathrm{p}<0.001\right)$, but propionate and butyrate concentrations were not $\left(r_{s}=-0.05, p>0.05 ; r_{s}=0.18, p>0.05\right.$, respectively). Arterial acetate concentrations correlated with those in the IMV and the portal vein $\left(r_{s}=0.65, p<0.01\right.$; $\mathrm{r}_{\mathrm{s}}=0.58, \mathrm{p}<0.01$, respectively) but not with those in the SMV $\left(r_{s}=0.31, p>0.05\right)$. Neither propionate nor butyrate concentrations in the different veins and the radial artery were correlated. Importantly, propionate and butyrate release by the distal intestines were $\sim 3$-fold higher than observed for the proximal intestines (propionate: $-63.8 \pm 13.4$ vs $-18.5 \pm 3.5$ $\mu \mathrm{mol} / \mathrm{L}$, butyrate: $-62.1 \pm 13.3$ vs $-21.8 \pm 7.4 \mu \mathrm{mol} / \mathrm{L}$ ), and acetate was only released to a significant extent by the distal intestines $(-79.9 \pm 25.5 \mu \mathrm{mol} / \mathrm{L})$. The liver showed a significant uptake of all SCFA (figure 1).

The higher SCFA release by the distal intestines relative to the proximal intestines may be explained in several ways. First, the mucosa of the proximal intestines may metabolise a relatively larger fraction of SCFA. ${ }^{5}$ Second, differences in

\begin{tabular}{lccclc}
\hline \multicolumn{7}{l}{ Table 1} & Arterial and venous SCFA concentrations \\
$\begin{array}{l}\text { Concentrations } \\
(\mu \mathrm{mol} / \mathrm{L})\end{array}$ & Radial artery & Hepatic vein & Portal vein & $\begin{array}{l}\text { Superior } \\
\text { mesenteric vein }\end{array}$ & $\begin{array}{l}\text { Inferior } \\
\text { mesenteric vein }\end{array}$ \\
\hline Acetate & $21.8 \pm 7.6$ & $23.6 \pm 4.8$ & $41.4 \pm 7.8$ & $50.4 \pm 11.3$ & $102.7 \pm 27.2$ \\
Propionate & $1.0 \pm 0.2$ & $2.8 \pm 0.8$ & $24.5 \pm 6.1$ & $19.5 \pm 3.5$ & $64.8 \pm 13.4$ \\
\hline Butyrate & $0.8 \pm 0.2$ & $2.6 \pm 0.8$ & $21.1 \pm 4.4$ & $22.7 \pm 7.4$ & $62.9 \pm 13.4$ \\
\hline SCFA, short-chain fatty acid. & & & &
\end{tabular}




\section{Proximal intestines}

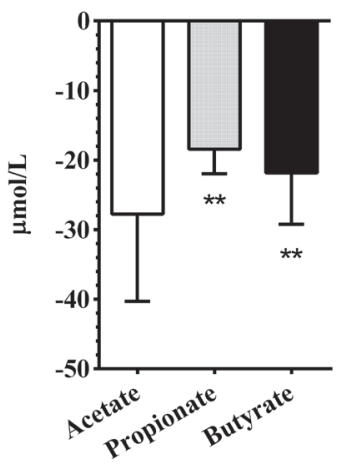

B

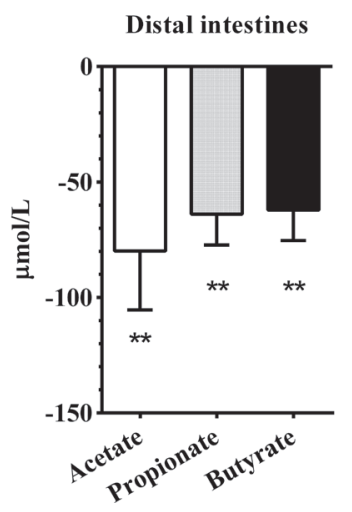

$\mathrm{C}$

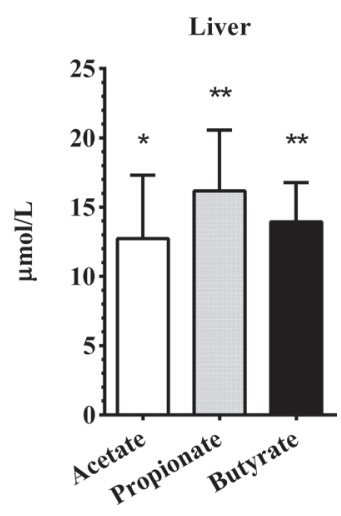

Figure 1 Arteriovenous differences in SCFA concentrations across (A) proximal intestines, (B) distal intestines and (C) liver. Positive values indicate net SCFA uptake, while negative values indicate net release. Asterisks indicate statistically significant uptake or release $\left({ }^{*} p<0.05\right.$; $\left.{ }^{* *} \mathrm{p}<0.001\right)$. SCFA, short-chain fatty acid.

local SCFA production may play a role. Indeed, the number of bacteria is highest in the colon, and gut microbiota composition and activity differ substantially between the proximal and distal intestines. ${ }^{6}$ However, SCFA concentrations are higher in the proximal intestinal lumen. Third, apical and basolateral epithelial cell uptake and transport of SCFA may differ between intestinal segments. To shed light on the importance of each of these potential mechanisms, studies combining analysis of the microbiota, intestinal/faecal SCFA concentrations, mucosal SCFA uptake and SCFA release are warranted.

These findings have implications for the development of nutritional strategies to modulate SCFA production and improve metabolic health: (1) slowly fermentable fibres that increase SCFA specifically in the distal intestines are expected to have higher potential for influencing host metabolism given the much higher SCFA release by the distal intestines, in line with the data of Chambers $e t a l^{4}$ and our recent work demonstrating that distal but not proximal acetate infusion promotes fat oxidation. ${ }^{8}$ (2) Given the substantial SCFA uptake by the liver, metabolic processes such as lipogenesis, gluconeogenesis and oxidation can be influenced by modulation of intestinal and portal SCFA levels through non-digestible carbohydrates or specific bacteria, depending on nutritional status. (3) Assessing systemic acetate levels might represent a practical way to monitor the efficacy of acetogenic dietary fibres directed to influence overall host metabolism, since arterial acetate concentrations correlate with those in the IMV and the portal vein.
Evelien PJG Neis, ${ }^{1,2}$ Hans MH van Eijk, ${ }^{1}$ Kaatje Lenaerts, ${ }^{1}$ Steven WM Olde Damink, ${ }^{1,3}$ Ellen E Blaak, ${ }^{2,4}$ Cornelis HC Dejong, ${ }^{1,2,3,5}$ Sander S Rensen ${ }^{1}$

${ }^{1}$ Department of Surgery, NUTRIM School for Nutrition and Translational Research in Metabolism, Maastricht University Medical Centre, Maastricht, The Netherlands ${ }^{2}$ Top Institute Food and Nutrition, Wageningen, The Netherlands

${ }^{3}$ Department of Surgery, Universitätsklinikum Aachen, Aachen, Germany

${ }^{4}$ Department of Human Biology, NUTRIM School for Nutrition and Translational Research in Metabolism, Maastricht University, Maastricht, The Netherlands ${ }^{5}$ GROW School for Oncology and Developmental Biology, Maastricht University, Maastricht, The Netherlands

Correspondence to Sander S Rensen, Department of Surgery, Maastricht University Medical Centre, PO Box 616, 6200 MD, Maastricht, The Netherlands; s.rensen@maastrichtuniversity.nl

Acknowledgements The authors would like to thank Dr Siamack Sabrkhany for help with patient inclusion.

Contributors CD and SR conceived and designed the study with input from the other authors. EPJGN SWOD, CD and HMHvE collected the data. EPJGN and SSR wrote the first draft of the paper. CD, EEB and SSR supervised the project and funded this study. EPJGN, SSR and HMHvE analysed the data. All authors interpreted the data and contributed to the writing of the paper. All authors revised and approved the final version.

Funding This study was funded by TI Food and Nutrition, a public-private partnership on precompetitive research in food and nutrition research. Partners are key players in the global food industry, leading research institutes, universities and medical centres.

Disclaimer The funders had no role in study design, data collection and analysis, decision to publish, or preparation of the manuscript.

Competing interests None declared.

\section{Patient consent Obtained}

Ethics approval This study was approved by the Medical Ethics Committee of Maastricht University Medical Centre (MEC 11-3-084) and was conducted according to the ethical standards of the Helsinki
Declaration of 1975 and in accordance with the Medical Research Involving Human Subjects Act (WMO). All patients provided verbal and written informed consent before surgery.

Provenance and peer review Not commissioned; externally peer reviewed.

(c) Article author(s) (or their employer(s) unless otherwise stated in the text of the article) 2019. All rights reserved. No commercial use is permitted unless otherwise expressly granted.

- Additional material is published online only. To view please visit the journal online (http://dx.doi.org/ 10.1136/gutjnl-2018-316161).

\section{(A) Check for updates}

To cite Neis EPJG, van Eijk HMH, Lenaerts K, et al. Gut 2019;68:764-765.

Received 8 February 2018

Revised 26 March 2018

Accepted 27 March 2018

Published Online First 4 April 2018

Gut 2019;68:764-765. doi:10.1136/ gutjnl-2018-316161

\section{REFERENCES}

1 Catry E, Bindels LB, Tailleux A, et al. Targeting the gut microbiota with inulin-type fructans: preclinical demonstration of a novel approach in the management of endothelial dysfunction. Gut 2018;67:271-83

2 Roager HM, Vogt JK, Kristensen M, et al. Whole grainrich diet reduces body weight and systemic low-grade inflammation without inducing major changes of the gut microbiome: a randomised cross-over trial. Gut 2019;68:83-93.

3 Li Z, Yi CX, Katiraei S, et al. Butyrate reduces appetite and activates brown adipose tissue via the gut-brain neural circuit. Gut 2018;67:1269-79.

4 Chambers ES, Viardot A, Psichas A, et al. Effects of targeted delivery of propionate to the human colon on appetite regulation, body weight maintenance and adiposity in overweight adults. Gut 2015;64:1744-54.

5 Topping DL, Clifton PM. Short-chain fatty acids and human colonic function: roles of resistant starch and nonstarch polysaccharides. Physiol Rev 2001:81:1031-64.

6 Thursby E, Juge N. Introduction to the human gut microbiota. Biochem J 2017;474:1823-36.

7 Cummings JH, Pomare EW, Branch WJ, et al. Short chain fatty acids in human large intestine, portal, hepatic and venous blood. Gut 1987;28:1221-7.

8 van der Beek CM, Canfora EE, Lenaerts K, et al. Distal, not proximal, colonic acetate infusions promote fat oxidation and improve metabolic markers in overweight/ obese men. Clin Sci 2016;130:2073-82. 